\title{
Physical and chemical properties of chicken mortadella formulated with Moringa oleifera Lam. seed flour
}

\author{
Bruna Emygdio AURIEMA ${ }^{1}$, Verena Pereira DINALLI ${ }^{1}$, Talita KATO ${ }^{1}$, Margarida Masami YAMAGUCHI ${ }^{2}$, \\ Denis Fabrício MARCHI ${ }^{3 *}$ (D), Adriana Lourenço SOARES ${ }^{1}$
}

\begin{abstract}
The objective of this study was to evaluate the effect of the addition of Moringa oleifera Lam. seed flour for partial fat replacement in chicken mortadella on physicochemical characteristics, chemical composition, and lipid oxidation. Four mortadellas were prepared: C (control), T1, T3, and T5 (addition of 1\%,3\%, and 5\% of moringa seed flour, respectively). T5 mortadella had the lowest lipid content $(p<0.05)$, whereas $C$ mortadella had the highest $(p<0.05)$. The addition of $5 \%$ of moringa seed flour affected color parameters, leading to an increase in $\mathrm{L}^{*}, \mathrm{a}^{*}$, and $\mathrm{b}^{*}$ values in comparison with the control. Color changes $(\Delta \mathrm{E})$ in T3 and T5 mortadellas were the lowest among the samples during a 90 -day storage period at $4{ }^{\circ} \mathrm{C}$. The addition of 3 or $5 \%$ of moringa seed flour promoted a reduction in lipid oxidation during storage. Moringa seeds have antioxidant activity and, therefore, have the potential to be used as a natural functional ingredient in meat products. The addition of $3 \%$ of moringa seed flour seemed to be ideal for chicken mortadella, as it reduced lipid content and promoted lipid stability without causing noticeable color changes during the 90 days of storage.
\end{abstract}

Keywords: lipid; lipid oxidation; antioxidant.

Practical Application: Improve the stability of meat products and decrease their fat content using Moringa oleifera Lam.

\section{Introduction}

Mortadella is a cured meat product that has high consumer acceptance in Brazil, where the average per capita consumption reaches $0.5 \mathrm{~kg}$ year $^{-1}$ (Instituto Brasileiro de Geografia e Estatística, 2017). The great popularity of mortadella is due to its fat content, as fats impart important sensorial characteristics, such as flavor, texture, and a desirable juiciness (Trindade et al., 2010). However, excessive fat consumption has adverse health effects, which include obesity and an increased risk of cardiovascular disease.

Consumers are becoming increasingly aware of their fat intake and concerned about the products they include in their diets, because lifestyle habits and a diet rich in saturated fats, cholesterol, and salt have been shown to be risk factors for cardiovascular disease. Consumer purchase decisions are influenced by convenience, health aspects, and a preference for low-fat, low-sodium, and reduced-calorie meat products (Shand et al., 1990).

Therefore, dietary fibers have been used in meat products not only as fat substitutes but also for their effects of reducing the risks of colon cancer, obesity, cardiovascular disease, and other health conditions (Chang \& Carpenter, 1997; Mansour \& Khalil, 1997).

Moringa oleifera Lam. is a medium-sized tree belonging to the family Moringaceae. It is native to northeastern India but also found in Egypt, Philippines, Sri Lanka, Thailand, Malaysia, Burma, Pakistan, Singapore, Jamaica, and Nigeria (Ramachandran et al., 1980). The leaves, flowers, and seeds have excellent nutritional value, and all parts of the plant have important medicinal properties (Makkar \& Becker, 1997). Moringa seeds have high fiber $\left(7.7 \mathrm{~g} 100 \mathrm{~g}^{-1}\right)$, protein $\left(38.3 \mathrm{~g} 100 \mathrm{~g}^{-1}\right)$, and lipid

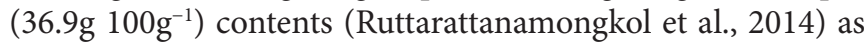
well as high antioxidant and antimicrobial activities (Singh et al., 2013) and, therefore, show potential as functional ingredients in meat emulsion products, such as mortadella. The objective of this work was to evaluate the effect of the addition of M. oleifera Lam. seed flour for partial fat replacement in chicken mortadella on physicochemical characteristics, chemical composition, and lipid oxidation.

\section{Materials and methods}

\subsection{Characterization of M. oleifera Lam. seeds}

Moringa seeds were purchased from a local producer in Maringá, PR, Brazil. Moringa seeds were manually peeled and crushed in an IKA ${ }^{\circledR}$ A11 Basic mill. Subsequently, seeds were sieved through a 20-mesh sieve. Ground moringa seeds (moringa seed flour) were subjected to physicochemical and antioxidant analyses 


\subsection{Physicochemical characterization of moringa seed flour}

Moisture, protein, lipid, fiber, and ash contents were determined according to AOAC methods (Association of Official Analytical Chemists, 2000). The $\mathrm{pH}$ was measured using a digital $\mathrm{pH}$ meter (Mettler Toledo FE20 Five Easy $\left.{ }^{\mathrm{TM}}\right)$. Water activity $\left(\mathrm{a}_{\mathrm{w}}\right)$ was measured using an Aqualab Dew Point 4TEV equipment. Water-holding capacity (WHC) was determined according to the method described by Robertson et al. (2000).

\subsection{Antioxidant activity of moringa seed flour}

Methanolic extracts of moringa seed flour were used for the determination of phenolic compounds and antioxidant activity. Phenolic compounds were determined by the method of Kumazawa et al. (2004), using the Folin-Ciocalteu reagent. Results were expressed as mg gallic acid equivalents (GAE). $100 \mathrm{~g}^{-1}$ dry weight. Antioxidant activity was determined by the ferric reducing antioxidant power (FRAP) and ABTS assays, according to the procedures described by Sánchez-González et al. (2005). Results were expressed in $\mu$ mol Trolox. $\mathrm{g}^{-1}$ sample dry weight. Analyses were carried out in triplicate.

\subsection{Preparation of chicken mortadella}

Mortadellas were prepared in pilot scale at the State University of Londrina (Londrina, PR, Brazil). Chicken breast meat and mechanically separated meat (MSM) were kindly provided by a commercial meat processing plant located in Londrina. Fat was purchased at local shops. All other ingredients were kindly provided by New Max Industrial Ltd.

Four different formulations of chicken mortadella were prepared using $0 \%$, (C, control), $1 \%(\mathrm{~T} 1), 3 \%$ (T3), and $5 \%$ (T5) of moringa seed flour as fat substitute. The maximum concentration of moringa seed flour (5\%) was defined to avoid imparting a bitter taste to mortadella; sensory evaluation showed that mortadellas containing more than $5 \%$ of moringa flour were bitter (data not shown).

First, cold chicken breast meat $\left(0^{\circ} \mathrm{C}\right)(30 \%)$ was cut into pieces and placed in a Sire cutter with ice (14\%). During comminution, mechanically deboned chicken meat $(27.32 \%)$ was added to the cutter. After homogenization, the remaining ingredients were added: salt (1.7\%) and fat (21\% for the control, $20 \%$ for $\mathrm{T} 1,18 \%$ for $\mathrm{T} 3$, and $16 \%$ for $\mathrm{T} 5$ ). The mixture was grinded for thirty seconds and then curing salt $(0.02 \%)$, soy protein isolate (2.2\%), moringa seed flour ( $1 \%$ for $\mathrm{T} 1,3 \%$ for $\mathrm{T} 3$, and $5 \%$ for T5), mortadella flavoring $(0.6 \%)$, cochineal carmine $(0.015 \%)$, antioxidant $(0.15 \%)$, and, finally, cassava starch $(3 \%)$ were added. Comminution was continued until the dough reached $7{ }^{\circ} \mathrm{C}$; temperature was controlled by a thermocouple. An aliquot was collected for weight determination as part of the analysis of emulsion stability, and the remainder of the dough was packed in polyamide casings (each mortadella had approximately $500 \mathrm{~g}$ ). Samples were cooked in a Dubnoff water bath under the following conditions: $20 \mathrm{~min}$ at $45^{\circ} \mathrm{C}, 20 \mathrm{~min}$ at $55^{\circ} \mathrm{C}, 20 \mathrm{~min}$ at $65^{\circ} \mathrm{C}$, $20 \mathrm{~min}$ at $75^{\circ} \mathrm{C}$. The samples were then kept at $85^{\circ} \mathrm{C}$ until the internal temperature reached $72{ }^{\circ} \mathrm{C}$. Mortadellas were stored under refrigeration $\left(4^{\circ} \mathrm{C}\right)$ for 40,60 , and 90 days. Analyses were performed in triplicate.

\subsection{Physicochemical analysis and proximate composition of chicken mortadella}

The proximate composition (moisture, protein, ash, and lipid contents) of mortadella was determined by AOAC methods (Association of Official Analytical Chemists, 2000). Moisture content was measured by oven drying the samples at $105^{\circ} \mathrm{C}$ to constant weight. Protein was quantified using the micro-Kjeldahl method. Ethereal extracts were obtained by the Soxhlet method. Ash content was determined by placing the samples in a muffle furnace at $550^{\circ} \mathrm{C}$.

Emulsion stability (ES) was determined according to the method proposed by Olivo et al. (1996), and results were expressed as percentage of weight loss $(\mathrm{w} / \mathrm{w})$.

Color parameters were determined on a Minolta ${ }^{\circledR}$ CR400 colorimeter using illuminant D65 and a $10^{\circ}$ viewing angle. Results were expressed in CIELab system: $L^{*}$ (lightness), $\mathrm{a}^{*}$ (red-green component), and $\mathrm{b}^{*}$ (yellow-blue component). Color measurements were carried out on the inside of each product at three different points per sample. The total color difference $(\Delta \mathrm{E})$ was calculated according to the equation: $\Delta \mathrm{E}=\left[\left(\mathrm{L}_{\mathrm{t} 0}^{*}-\mathrm{L}_{\mathrm{t}}^{*}\right)^{2}+\left(\mathrm{a}_{\mathrm{t} 0}^{*}-\mathrm{a}_{\mathrm{t}}^{*}\right)^{2}+\left(\mathrm{b}_{\mathrm{t} 0}^{*}-\mathrm{b}_{\mathrm{t}}^{*}\right)^{2}\right]^{1 / 2}$, where $\mathrm{t}_{0}$ represents mortadella samples stored for $24 \mathrm{~h}$ (time 0 ) and $\mathrm{t}$ represents mortadella samples after 40,60 , or 90 days of storage at $4{ }^{\circ} \mathrm{C}$.

Water activity $\left(\mathrm{a}_{\mathrm{w}}\right)$ was measured using the Aqualab equipment, and the $\mathrm{pH}$ was measured using the Mettler Toledo $\mathrm{pH}$ meter.

Water-holding capacity (WHC) was measured by the method of Troy et al. (1999). Approximately $10 \mathrm{~g}$ of sample per treatment was weighed into a glass jar and kept at $90^{\circ} \mathrm{C}$ for $10 \mathrm{~min}$ in a water bath. After heated, samples were carefully removed from the jars using a pair of tweezers. When the samples had cooled to room temperature, they were wrapped in cotton cheesecloth and placed into $50 \mathrm{~mL}$ polycarbonate centrifuge tubes with enough absorbent cotton wool on the bottom. Samples were centrifuged for $10 \mathrm{~min}$ at $9000 \times \mathrm{g}$ and $4^{\circ} \mathrm{C}$ and then reweighed. The results were expressed as percentages.

Texture characteristics were evaluated on a Universal Stable Micro Systems TA.XT2i texture analyzer equipped with a P035 metal probe. Samples were cut into cylinders of $3 \mathrm{~cm}$ in diameter and $2.2 \mathrm{~cm}$ in length. The parameters used to analyze the mechanical properties of mortadellas were defined by Civille \& Szczesniak (1973): hardness, elasticity, cohesiveness, and chewiness (chewiness $=$ hardness $\times$ cohesiveness $\times$ elasticity).

\subsection{Lipid oxidation}

Lipid oxidation was evaluated in mortadella samples after $24 \mathrm{~h}$ (time 0 ) and 40,60 , and 90 days of storage at $4{ }^{\circ} \mathrm{C}$ by the TBARS (thiobarbituric acid reactive substances) assay (Tarladgis et al., 1960) using sulfanilamide. Lipid oxidation was expressed as mg TBARS. $\mathrm{kg}^{-1}$ sample.

\subsection{Statistical analysis}

Results were analyzed using Statistica 7.0 software (StatSoft). Data were submitted to analysis of variance (ANOVA), and Tukey test at $5 \%$ probability was used for comparisons among different mortadella formulations. 


\section{Results and discussion}

\subsection{Characterization of M. oleifera Lam. seed flour}

Lipids (38.6 $100 \mathrm{~g}^{-1}$ ) were the main components of moringa seed flour. The second most abundant components were fibers

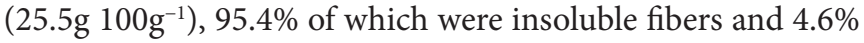
of which were soluble fibers (Table 1). The third most abundant

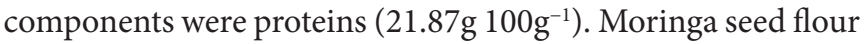
also contained phenolic compounds ( $6.09 \mathrm{mg} \mathrm{GAE}^{-1}$ dry weight) and showed antioxidant activity by the FRAP and ABTS assays.

The relatively high dietary fiber content, the relatively low water activity (0.59) (Table 1), and the $\mathrm{pH}$ of moringa seed flour (similar to that of chicken breast meat; $\mathrm{pH} 6.2$ vs. 6.6, respectively) (Dransfield \& Sosnicki, 1999) indicate its potential as a fiber-rich functional ingredient for meat products. The phenolic content and antioxidant activity (Table 1) of moringa seed flour suggest that it can be used to improve the oxidative stability of meat products.

The WHC of moringa seed flour was relatively low $\left(1.8 \mathrm{~g} \mathrm{~g}^{-1}\right)$ in comparison with that of apple fiber $\left(6.12 \mathrm{~g} \mathrm{~g}^{-1}\right)$ (Rosell et al., 2009). However, apple fibers were isolated in the referred study, whereas in this study, we used whole moringa seed flour without any extraction process, lowering production costs.

\subsection{Evaluation of chicken mortadella prepared with the addition of M. oleifera Lam. seed flour}

The moisture, ash, and protein contents of chicken mortadella did not differ ( $p>0.05)$ among formulations (Table 2). Lipid contents differed significantly $(\mathrm{p}<0.05)$; $\mathrm{C}$ mortadella had the highest lipid content, T5 mortadella presented the lowest content, and $\mathrm{T} 1$ and $\mathrm{T} 3$ mortadellas presented intermediate values that did not differ $(\mathrm{p}>0.05)$ from each other. T1 and T3 mortadellas had their lipid content reduced by $11.6 \%$ in comparison with C mortadella, whereas T5 mortadella had a reduction of $18.7 \%$ in comparison with the control.

The low lipid content of T5 mortadella was due to the partial replacement of fat by moringa seed flour (Table 2), even though the flour contains $38.6 \mathrm{~g}$ lipids $100 \mathrm{~g}^{-1}$ (Table 1 ).

ES and WHC of the mortadellas were not affected by the addition of moringa seed flour (Table 3 ). These properties tend to decrease when there is insufficient protein to emulsify fats and form a gelled protein matrix capable of preventing the separation of fats and other constituents.

ES and WHC did not differ ( $p>0.05)$ among $C, T 1, T 3$, and T5 mortadellas (Table 3 ). T5 mortadella had a lower $\mathrm{a}_{\mathrm{w}}$ than C and T1 mortadellas, but the $\mathrm{a}_{\mathrm{w}}$ of T5 did not differ $(\mathrm{p}>0.05)$ from that of T3. $\mathrm{pH}$ values of $\mathrm{T} 3$ and $\mathrm{T} 5$ mortadellas were lower $(\mathrm{p}<0.05)$ than those of $\mathrm{C}$ and $\mathrm{T} 1$.

The addition of $5 \%$ of moringa seed flour caused a decrease in $a_{w}$ in comparison with the control (Table 3), as moringa seed flour had a relatively low $a_{w}$ (Table 1 ). The addition of 3 or $5 \%$ of moringa seed flour reduced mortadella $\mathrm{pH}$ (Table 3 ). The same result was observed in a study by Sharaf et al. (2009) analyzing beef burgers prepared with $9-12 \%$ of $M$. oleifera seed flour.
The hardness and chewiness of $\mathrm{C}$ mortadella were higher than those of other mortadellas (Table 4). The elasticity and cohesiveness of T5 mortadella were significantly lower $(\mathrm{p}<0.05)$ than those of $\mathrm{C}$ mortadella but did not differ $(\mathrm{p}>0.05)$ from those of the other formulations.

The replacement of fat by $5 \%$ of moringa seed flour resulted in a mortadella with a smooth texture (Table 4). Yang et al. (2007) reported that the addition of hydrated oat flour as a fat substitute

Table 1. Proximate composition, water activity $\left(\mathrm{a}_{\mathrm{w}}\right)$, water-holding capacity (WHC), and antioxidant capacity of Moringa oleifera Lam. seed flour.

\begin{tabular}{|c|c|}
\hline Variable & Moringa seed flour \\
\hline Moisture (g.100g ${ }^{-1}$ ) & $6.92 \pm 0.062$ \\
\hline Lipids (g.100g $\mathrm{g}^{-1}$ ) & $38.63 \pm 0.699$ \\
\hline Proteins (g. $100 \mathrm{~g}^{-1}$ ) & $21.87 \pm 0.662$ \\
\hline Ash $\left(g .100 g^{-1}\right)$ & $3.02 \pm 0.010$ \\
\hline Total Carbohydrates (g.100g $\mathrm{g}^{-1}$ ) & 3.97 \\
\hline Total Dietary Fibers (g.100g $\mathrm{g}^{-1}$ ) & 25.59 \\
\hline Soluble Dietary Fibers (g.100g $\mathrm{g}^{-1}$ ) & 1.27 \\
\hline Insoluble Dietary Fibers (g.100g ${ }^{-1}$ ) & 24.32 \\
\hline WHC ( $\mathrm{g} \mathrm{H}_{2} \mathrm{O}^{-1}{ }^{-1}$ sample $)$ & $1.80 \pm 0.025$ \\
\hline$a_{w}$ & $0.59 \pm 0.002$ \\
\hline $\mathrm{pH}$ & $6.20 \pm 0.011$ \\
\hline Total Phenolic Compounds (mg GAE.g $\left.{ }^{-1}\right)^{\mathrm{a}}$ & 6.09 \\
\hline FRAP $\left(\mu \mathrm{mol} . \mathrm{g}^{-1}\right)^{\mathrm{b}}$ & 8.27 \\
\hline $\operatorname{ABTS}\left(\mu \mathrm{mol} \cdot \mathrm{g}^{-1}\right)^{\mathrm{b}}$ & 11.91 \\
\hline
\end{tabular}

${ }^{a}$ Results are expressed as mg gallic acid equivalents (GAE) $\mathrm{g}^{-1}$ dry weight; ${ }^{\mathrm{b}}$ Results are expressed as $\mu \mathrm{mol}$ Trolox $\mathrm{g}^{-1}$ dry weight.

Table 2. Proximate composition of chicken mortadella prepared with the addition of $0,1,3$, or $5 \%$ of Moringa oleifera Lam. seed flour.

\begin{tabular}{ccccc}
\hline Formulation & Moisture (\%) & Ash (\%) & Protein (\%) & Lipid (\%) \\
\hline C & $60.22 \pm 0.55^{\mathrm{a}}$ & $2.90 \pm 0.03^{\mathrm{a}}$ & $13.43 \pm 0.26^{\mathrm{a}}$ & $22.34 \pm 0.44^{\mathrm{a}}$ \\
T1 & $60.21 \pm 0.69^{\mathrm{a}}$ & $2.89 \pm 0.04^{\mathrm{a}}$ & $13.53 \pm 0.10^{\mathrm{a}}$ & $19.79 \pm 0.61^{\mathrm{b}}$ \\
T3 & $60.57 \pm 0.85^{\mathrm{a}}$ & $3.02 \pm 0.13^{\mathrm{a}}$ & $13.85 \pm 0.24^{\mathrm{a}}$ & $19.70 \pm 0.49^{\mathrm{b}}$ \\
T5 & $60.67 \pm 0.19^{\mathrm{a}}$ & $2.97 \pm 0.09^{\mathrm{a}}$ & $14.03 \pm 0.60^{\mathrm{a}}$ & $18.17 \pm 0.24^{\mathrm{c}}$ \\
\hline
\end{tabular}

Results are expressed as mean \pm standard deviation. Means followed by different letters within a column are significantly different $(\mathrm{p}<0.05) . \mathrm{C}=$ control; $\mathrm{T} 1=$ mortadella prepared with the addition of $1 \%$ of moringa seed flour and $1 \%$ fat reduction; $\mathrm{T} 3$ = mortadella prepared with the addition of $3 \%$ of moringa seed flour and $3 \%$ fat reduction; $\mathrm{T} 5=$ mortadella prepared with the addition of $5 \%$ of moringa seed flour and $5 \%$ fat reduction.

Table 3. Emulsion stability (ES), water-holding capacity (WHC), water activity $\left(\mathrm{a}_{\mathrm{w}}\right)$, and $\mathrm{pH}$ of chicken mortadella prepared with the addition of $0,1,3$, or $5 \%$ of Moringa oleifera Lam. seed flour.

\begin{tabular}{ccccc}
\hline Formulation & ES (\%) & WHC (\%) & $\mathrm{a}_{\mathrm{w}}$ & $\mathrm{pH}$ \\
\hline C & $99.89 \pm 0.05^{\mathrm{a}}$ & $96.51 \pm 0.24^{\mathrm{a}}$ & $0.977 \pm 0.004^{\mathrm{a}}$ & $6.21 \pm 0.13^{\mathrm{a}}$ \\
T1 & $99.30 \pm 0.14^{\mathrm{b}}$ & $96.17 \pm 0.12^{\mathrm{a}}$ & $0.976 \pm 0.001^{\mathrm{a}}$ & $6.19 \pm 0.12^{\mathrm{a}}$ \\
T3 & $99.89 \pm 0.07^{\mathrm{a}}$ & $96.24 \pm 0.15^{\mathrm{a}}$ & $0.975 \pm 0.002^{\mathrm{ab}}$ & $5.85 \pm 0.17^{\mathrm{b}}$ \\
T5 & $99.80 \pm 0.20^{\mathrm{a}}$ & $96.3 \pm 0.29^{\mathrm{a}}$ & $0.972 \pm 0.002^{\mathrm{b}}$ & $5.73 \pm 0.19^{\mathrm{b}}$ \\
\hline
\end{tabular}

Results are expressed as mean \pm standard deviation. Means followed by different letters within a column are significantly different $(\mathrm{p}<0.05) . \mathrm{C}=$ control; $\mathrm{T} 1=$ mortadella prepared with the addition of $1 \%$ of moringa seed flour and $1 \%$ fat reduction; $\mathrm{T} 3=$ mortadella prepared with the addition of $3 \%$ of moringa seed flour and $3 \%$ fat reduction; $\mathrm{T} 5=$ mortadella prepared with the addition of $5 \%$ of moringa seed flour and $5 \%$ fat reduction. 
Table 4. Texture analysis (hardness, elasticity, cohesiveness, and chewiness) of chicken mortadella prepared with the addition of $0,1,3$, or $5 \%$ of Moringa oleifera Lam. seed flour.

\begin{tabular}{ccccc}
\hline Formulation & Hardness $(\mathrm{N})$ & $\begin{array}{c}\text { Elasticity } \\
(\mathrm{mm})\end{array}$ & Cohesiveness & $\begin{array}{c}\text { Chewiness } \\
(\mathrm{N} \mathrm{mm})\end{array}$ \\
\hline C & $111.6 \pm 6.62^{\mathrm{a}}$ & $0.8258 \pm 0.01^{\mathrm{a}}$ & $0.6636 \pm 0.02^{\mathrm{a}}$ & $61.22 \pm 4.86^{\mathrm{a}}$ \\
T1 & $94.83 \pm 8.17^{\mathrm{b}}$ & $0.8001 \pm 0.03^{\mathrm{ab}}$ & $0.6451 \pm 0.07^{\mathrm{ab}}$ & $48.96 \pm 7.16^{\mathrm{b}}$ \\
T3 & $71.28 \pm 5.28^{\mathrm{c}}$ & $0.7988 \pm 0.02^{\mathrm{ab}}$ & $0.5288 \pm 0.12^{\mathrm{bc}}$ & $28.85 \pm 5.46^{\mathrm{c}}$ \\
T5 & $63.04 \pm 6.49^{\mathrm{c}}$ & $0.7908 \pm 0.01^{\mathrm{b}}$ & $0.4574 \pm 0.07^{\mathrm{c}}$ & $22.80 \pm 4.25^{\mathrm{c}}$ \\
\hline
\end{tabular}

Results are expressed as mean \pm standard deviation. Means followed by different letters within a column are significantly different $(\mathrm{p}<0.05) . \mathrm{C}=$ control; $\mathrm{T} 1=$ mortadella prepared with the addition of $1 \%$ of moringa seed flour and $1 \%$ fat reduction; $\mathrm{T} 3=$ mortadella prepared with the addition of $3 \%$ of moringa seed flour and $3 \%$ fat reduction; T5 = mortadella prepared with the addition of $5 \%$ of moringa seed flour and $5 \%$ fat reduction.

$(10,15$, and $25 \%)$ in sausages yielded products with lower hardness, cohesiveness, and chewiness but that did not differ in elasticity. However, other authors have reported an increase in hardness of emulsified products as a result of the addition of fibers from different sources (Pietrasik \& Janz, 2010; Viuda-Martos et al., 2010; Huang et al., 2011). According to Grigelmo-Miguel et al. (1999) fiber may interfere with the protein-protein and protein-water interactions of the gel network, leading to a decrease in hardness. Thus, the addition of $5 \%$ of moringa seed flour may have affected the gel network of the mortadella.

The $\mathrm{L}^{\star}$ values (Table 5) of T3 and T5 mortadellas were higher $(\mathrm{p}<0.05)$ than those of T1 and C after $24 \mathrm{~h}$ of storage (time 0 ). $\mathrm{L}^{\star}$ values varied with storage time for all mortadellas except $\mathrm{T} 3$, for which $\mathrm{L}^{*}$ values remained constant during storage.

The addition of $5 \%$ of moringa seed flour resulted in lighter-colored mortadella. These results are in agreement with those obtained by Al-Juhaimi et al. (2016) who observed an increase in lightness in hamburger meat by adding moringa seed flour $(2,4$, and $6 \%)$. The increase in lightness may be associated with the color of moringa seed flour.

Regarding $\mathrm{a}^{*}$ values (Table 5), after $24 \mathrm{~h}$ of storage (time 0 ) only T5 mortadella differed $(\mathrm{p}<0.05)$ from other mortadellas. After 40 and 60 days of storage, the $\mathrm{a}^{*}$ value of T5 mortadella did not differ $(p>0.05)$ from that of $C$ mortadella but differed $(\mathrm{p}<0.05)$ from those of $\mathrm{T} 1$ and T3 mortadellas. After 90 days, $\mathrm{T} 1, \mathrm{~T} 3$, and T5 mortadellas did not differ $(\mathrm{p}<0.05)$ in color from $\mathrm{C}$ mortadella.

The addition of 5\% of moringa seed flour yielded a product with a redder color (higher $\mathrm{a}^{*}$ value) probably because of the presence of phenolic compounds and antioxidant activity (Table 1), favoring the reduction of nitrosomyoglobin.

After $24 \mathrm{~h}$ of storage, T3 and T5 mortadellas exhibited an increase in $b^{*}$ value $(\mathrm{p}<0.05)$ in comparison with $\mathrm{C}$ and $\mathrm{T} 1$ mortadellas (Table 5). After 40 days of storage, no difference was observed among mortadellas. After 60 days, $\mathrm{C}$ mortadella had the highest $\mathrm{b}^{\star}$ value, followed by T3, T5, and T1 mortadellas. At the end of the storage period, the $b^{*}$ value of T3 differed $(\mathrm{p}<0.05)$ from that of $\mathrm{C}$ and $\mathrm{T} 1$ but did not differ $(\mathrm{p}>0.05)$ from that of $\mathrm{T} 5$.
Table 5. Evaluation of $\mathrm{L}^{\star}, \mathrm{a}^{\star}, \mathrm{b}^{\star}$ values of chicken mortadella prepared with the addition of $0,1,3$, or $5 \%$ of Moringa oleifera Lam. seed flour during storage at $4{ }^{\circ} \mathrm{C}$.

\begin{tabular}{|c|c|c|c|c|}
\hline \multirow{2}{*}{ Formulation } & \multicolumn{4}{|c|}{$\mathrm{L}^{*}$ values during storage (days) } \\
\hline & 0 & 40 & 60 & 90 \\
\hline $\mathrm{C}$ & $69.48 \pm 0.56^{\mathrm{bC}}$ & $72.02 \pm 0.59^{\mathrm{bA}}$ & $71.1 \pm 0.27^{\mathrm{dB}}$ & $70.38 \pm 0.36^{\mathrm{bC}}$ \\
\hline $\mathrm{T} 1$ & $69.94 \pm 0.88^{\mathrm{bC}}$ & $71.73 \pm 0.16^{\mathrm{bB}}$ & $79.25 \pm 0.27^{\mathrm{aA}}$ & $70.25^{ \pm} 0.23^{\mathrm{bC}}$ \\
\hline T3 & $72.83 \pm 0.90^{\mathrm{aA}}$ & $73.50 \pm 1.36^{\mathrm{bA}}$ & $72.40 \pm 0.83^{\mathrm{cA}}$ & $72.87 \pm 0.81^{\mathrm{aA}}$ \\
\hline \multirow[t]{3}{*}{ T5 } & $72.20 \pm 0.92^{\mathrm{aC}}$ & $73.13 \pm 0.60^{\mathrm{aB}}$ & $74.90 \pm 0.28^{\mathrm{bA}}$ & $72.85 \pm 0.58^{\mathrm{aB}}$ \\
\hline & \multicolumn{4}{|c|}{$\mathrm{a}^{*}$ values during storage (days) } \\
\hline & 0 & 40 & 60 & 90 \\
\hline $\mathrm{C}$ & $11.53 \pm 0.97^{\mathrm{bB}}$ & $14.08 \pm 0.85^{\mathrm{aA}}$ & $10.99 \pm 0.18^{\mathrm{cB}}$ & $11.72 \pm 0.25^{\mathrm{abB}}$ \\
\hline $\mathrm{T} 1$ & $12.48 \pm 0.53^{\mathrm{bC}}$ & $14.61 \pm 0.49^{\mathrm{aB}}$ & $15.79 \pm 0.15^{\mathrm{aA}}$ & $12.54 \pm 0.44^{\mathrm{aC}}$ \\
\hline $\mathrm{T} 3$ & $11.69 \pm 0.47^{\mathrm{bB}}$ & $12.01 \pm 0.31^{\mathrm{cB}}$ & $12.24 \pm 0.39^{\mathrm{bA}}$ & $11.08 \pm 0.83^{\mathrm{bB}}$ \\
\hline \multirow[t]{3}{*}{ T5 } & $12.71 \pm 1.38^{\mathrm{aA}}$ & $13.49 \pm 0.18^{\mathrm{bA}}$ & $10.67 \pm 0.25^{\mathrm{cC}}$ & $11.16 \pm 0.53^{\mathrm{bB}}$ \\
\hline & \multicolumn{4}{|c|}{$\mathrm{b}^{*}$ values during storage (days) } \\
\hline & 0 & 40 & 60 & 90 \\
\hline $\mathrm{C}$ & $12.05 \pm 0.82^{\mathrm{bB}}$ & $12.50 \pm 0.66^{\mathrm{aB}}$ & $14.56 \pm 0.02^{\mathrm{aA}}$ & $14.60 \pm 0.29^{\mathrm{abA}}$ \\
\hline $\mathrm{T} 1$ & $11.59 \pm 0.22^{\mathrm{bB}}$ & $12.53 \pm 0.17^{\mathrm{aB}}$ & $12.19 \pm 0.23^{\mathrm{dC}}$ & $14.64 \pm 0.11^{\mathrm{aA}}$ \\
\hline T3 & $12.74 \pm 0.65^{\mathrm{aAB}}$ & $12.47 \pm 0.22^{2 \mathrm{~B}}$ & $13.09 \pm 0.29^{\mathrm{bA}}$ & $13.42 \pm 0.53^{\mathrm{cAB}}$ \\
\hline T5 & $12.32 \pm 0.24^{\mathrm{bB}}$ & $12.44 \pm 0.08^{\mathrm{aB}}$ & $12.62 \pm 0.11^{\mathrm{cB}}$ & $13.42 \pm 0.22^{\mathrm{bcA}}$ \\
\hline
\end{tabular}

The inclusion of 3 or $5 \%$ of moringa seed flour caused an increase in $b^{*}$ value, yielding a more yellowish product. This increase may be due to the presence of carotenoids in moringa seed flour.

The total color difference $(\Delta \mathrm{E})$ of T3 and T5 mortadellas after 40 days of storage was lower $(\mathrm{p}<0.05)$ in comparison with $\mathrm{T} 1$ and $\mathrm{C}$ mortadellas (Figure 1). After 60 days, T3 showed the smallest $\Delta \mathrm{E}$; and $\mathrm{T} 1$, the greatest. After 90 days, there was no significant difference ( $\mathrm{p}>0.05)$ in $\Delta \mathrm{E}$ among $\mathrm{C}, \mathrm{T} 1$, and $\mathrm{T} 5$ mortadellas. However, $\mathrm{T} 3$ mortadella had a lower $\Delta \mathrm{E}$ than the other formulations.

The total color difference is considered to be perceptible to the human eye when $\Delta \mathrm{E}$ is greater than 2 (Moarefian et al., 2011). On this basis, $C$ and $T 1$ mortadellas had a noticeable color difference after 40, 60, and 90 days of storage, and T5 mortadella showed no noticeable difference in color up to 40 days of storage. T3 mortadella showed no noticeable color difference throughout the entire storage period, suggesting that the addition of $3 \%$ of moringa seed flour inhibited color changes during product storage.

\subsection{Lipid oxidation}

Figure 2 shows the effect of moringa seed flour on chicken mortadella lipid oxidation during storage. After $24 \mathrm{~h}$ of storage (time 0 ), T3 and T5 mortadellas had lower TBARS levels $(\mathrm{p}<0.05)$ than $\mathrm{C}$ and $\mathrm{T} 1$ mortadellas. After 40 days of storage, lower TBARS values were observed for T3 (0.160mg TBARS $\mathrm{kg}^{-1}$ sample) and T5 mortadellas ( $0.184 \mathrm{mg}$ TBARS $\mathrm{kg}^{-1}$ sample), having no significant difference $(\mathrm{p}>0.05)$ between these results. The highest TBARS value was observed for $\mathrm{C}$ mortadella (2.542 $\mathrm{mg} \mathrm{TBARS} \mathrm{kg}^{-1}$ sample). 


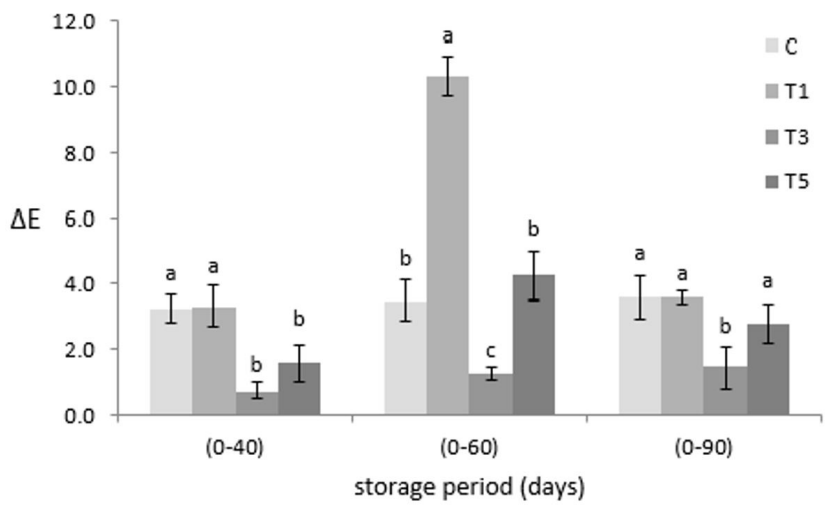

Figure 1. Total color difference $(\Delta \mathrm{E})$ of chicken mortadella prepared with the addition of $0,1,3$, or $5 \%$ of Moringa oleifera Lam. seed flour after processing and storage at $4{ }^{\circ} \mathrm{C}$. $\mathrm{C}=$ control; $\mathrm{T} 1=$ mortadella prepared with the addition of $1 \%$ of moringa seed flour and $1 \%$ fat reduction; $\mathrm{T} 3=$ mortadella prepared with the addition of $3 \%$ of moringa seed flour and 3\% fat reduction; T5 = mortadella prepared with the addition of $5 \%$ of moringa seed flour and $5 \%$ fat reduction. ${ }^{a-c}$ For each storage period, means followed by different letters differ by the Tukey test at the $5 \%$ probability level.

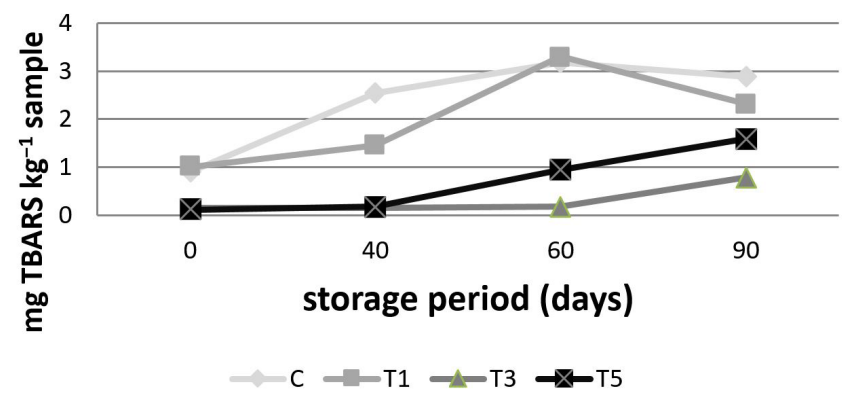

Figure 2. Evaluation of lipid oxidation (mg TBARS $\mathrm{kg}^{-1}$ sample) in chicken mortadella prepared with the addition of $0,1,3$, or $5 \%$ of Moringa oleifera Lam. seed flour during storage at $4{ }^{\circ} \mathrm{C}$. C $=$ control; $\mathrm{T} 1=$ mortadella prepared with the addition of $1 \%$ of moringa seed flour and $1 \%$ fat reduction; $\mathrm{T} 3=$ mortadella prepared with the addition of $3 \%$ of moringa seed flour and 3\% fat reduction; T5 = mortadella prepared with the addition of $5 \%$ of moringa seed flour and $5 \%$ fat reduction.

After 60 days of storage, the TBARS value of T3 mortadella was lower $(\mathrm{p}<0.05)$ than that of other formulations. The second lowest TBARS value was observed for T5 mortadella, and the oxidation levels of $\mathrm{C}$ and $\mathrm{T} 1$ mortadellas were not significantly different $(p>0.05)$. At the end of the storage period (90 days), the lowest level of lipid oxidation $(\mathrm{p}<0.05)$ was observed for T3 mortadella and the highest level for C mortadella. T1 and T5 mortadellas had intermediate TBARS values.

C mortadella was $64 \%$ more oxidized after 40 days of storage in relation to time 0 . The TBARS value of $\mathrm{T} 1$ mortadella increased until day 60 and then decreased by $31 \%$ at 90 days of storage in relation to time 0 . The lipid oxidation of $\mathrm{T} 3$ mortadella remained constant up to 60 days of storage, and at the end of the 90 days, there was an increase in the TBARS value. For T5 mortadella, lipid oxidation remained constant for 40 days and increased slightly thereafter.

Moringa seed flour reduced lipid oxidation in chicken mortadella (Figure 2). After $24 \mathrm{~h}$ of storage (time 0), $88.9 \%$ of TBARS formation was inhibited in T3 and T5 mortadellas in comparison with the control. After 40 days, $40 \%$ of lipid oxidation was inhibited in T1 mortadella and $92 \%$ in T3 and T5 mortadellas in comparison with C mortadella. After 60 days of storage, lipid oxidation was inhibited by $93.7 \%$ and $71.8 \%$ in T3 and T5 mortadellas, respectively. At the end of the storage period, $72.4 \%$ and $44.8 \%$ of lipid oxidation was inhibited in T3 and T5 mortadellas, respectively, in comparison with C mortadella. The results indicate that the addition of 3 or $5 \%$ of moringa seed flour in chicken mortadella contributed to the reduction of lipid oxidation. This effect may be attributed to the presence of phenolic compounds with antioxidant activity in moringa seed, evidenced by FRAP and ABTS analyses (Table 1).

\section{Conclusion}

Moringa seed flour presented antioxidant activity, which indicates its potential as a natural and functional ingredient in meat products. The formulation containing $3 \%$ of moringa seed flour seemed to be ideal for chicken mortadella, as it resulted in a product with reduced lipid content and increased lipid stability, without causing noticeable color changes during the 90-day storage period.

\section{Acknowledgements}

The authors thank the Brazilian National Council for Scientific and Technological Development $(\mathrm{CNPq})$ for the funding of this project (protocol no. 471609/2011-0).

\section{References}

Al-Juhaimi, F., Ghafoor, K., Hawashin, M. D., Alsawmahi, O. N., \& Babiker, E. E. (2016). Effects of different levels of Moringa (Moringa oleifera) seed flour on quality attributes of beef burgers. CYTA: Journal of Food, 14(1), 1-9. http://dx.doi.org/10.1080/19476337.2 015.1034784.

Association of Official Analytical Chemists - AOAC. (2000). Official Methods of Analysis of AOAC International (17th ed.). Gaithersburg: AOAC International.

Chang, H. C., \& Carpenter, J. A. (1997). Optimizing quality of frankfurters containing oat bran and added water. Journal of Food Science, 62(1), 194-202. http://dx.doi.org/10.1111/j.1365-2621.1997.tb04398.x.

Civille, G. V., \& Szczesniak, L. (1973). Guidelines to training a texture profile panel. Journal of Texture Studies, 4(2), 204-223. http://dx.doi. org/10.1111/j.1745-4603.1973.tb00665.x.

Dransfield, E., \& Sosnicki, A. A. (1999). Relationship between muscle growth and poultry meat quality. Poultry Science, 78(5), 743-746. http://dx.doi.org/10.1093/ps/78.5.743. PMid:10228972.

Grigelmo-Miguel, N., Abadías-Serós, M. A., \& Martín-Belloso, O. (1999). Characterisation of low-fat high-dietary fibre frankfurters. Meat Science, 52(3), 247-256. http://dx.doi.org/10.1016/S03091740(98)00173-9. PMid:22062572.

Huang, S. C., Tsai, Y. F., \& Chen, C. M. (2011). Effects of wheat fiber, oat fiber, and inulin on sensory and physico-chemical properties of 
Chinese-style sausages. Asian-Australasian Journal Animal Science, 24(6), 875-880. http://dx.doi.org/10.5713/ajas.2011.10317.

Instituto Brasileiro de Geografia e Estatística - IBGE. (2017). Search of family budget. Retrieved from http://www.ibge.gov.br/home/estatistica/ populacao/condicaodevida/pof/2008_2009_analise_consumo/ pofanalise_2008_2009.pdf

Kumazawa, S., Hamasaka, T., \& Nakauama, T. (2004). Antioxidant activity of propolis of various geographic origins. Food Chemistry, 64(3), 329-339. http://dx.doi.org/10.1016/S0308-8146(03)00216-4.

Makkar, H. P. S., \& Becker, K. (1997). Nutrients and antiquality factors in different morphological parts of the Moringa oleifera tree. The Journal of Agricultural Science, 128(3), 311-322. http://dx.doi. org/10.1017/S0021859697004292.

Mansour, E. H., \& Khalil, A. H. (1997). Characteristics of low-fat beefburger as influenced by various types of wheat fibers. Food Research International, 30(3-4), 199-205. http://dx.doi.org/10.1016/ S0963-9969(97)00043-4.

Moarefian, M., Barzegar, M., \& Sattari, M. (2011). Cinnamomum zeylanicum essential oil as a natural antioxidant and antibacterial in cooked sausage. Journal of Food Biochemistry, 37, 1745-4514.

Olivo, R., Betanho, C., Dagli, M. L. Z., \& Shimokomaki, M. (1996). Como as fibras de colágeno estabilizam uma emulsão cárnea. National Meat Journal, 230, 20-24.

Pietrasik, Z., \& Janz, J. A. M. (2010). Utilization of pea flour, starch-rich and fiber-rich fractions in low-fat Bologna. Food Research International, 43(2), 602-608. http://dx.doi.org/10.1016/j.foodres.2009.07.017.

Ramachandran, C., Peter, K. V., \& Gopalakrishnan, P. K. (1980). Drumstick (Moringa oleifera): a multipurpose Indian vegetable. Economic Botany, 34(3), 276-283. http://dx.doi.org/10.1007/BF02858648.

Robertson, J. A., Monredon, F. D., Dysseler, P., Guillon, F., Renato Amado, R., \& Thibault, J. F. (2000). Hydration properties of dietary fibre and resistant starch: a European collaborative study. Food Science and Technology (Campinas), 33, 72-79.

Rosell, C. M., Santos, E., \& Collar, C. (2009). Physico-chemical properties of commercial fibres from different sources: A comparative approach. Food Research International, 42(1), 176-184. http://dx.doi. org/10.1016/j.foodres.2008.10.003.

Ruttarattanamongkol, K., Siebenhandl-ehn, S., Schreiner, M., \& Petrash, A. (2014). Pilot-scale supercritical carbon dioxide extraction, physicochemical properties and profile characterization of Moringa oleífera seed oil in comparison with conventional extraction methods.
Industrial Crops and Products, 58, 68-77. http://dx.doi.org/10.1016/j. indcrop.2014.03.020.

Sánchez-González, I., Jiménez-Escrig, A., \& Saura-Calixto, F. (2005). In vitro antioxidant activity of coffees brewed using different procedures (italian, espresso and filter). Food Chemistry, 90(1-2), 133-139. http:// dx.doi.org/10.1016/j.foodchem.2004.03.037.

Shand, J. S., Schmidt, G. R., Mandigo, R. W., \& Claus, J. R. (1990). New technology for low-fat meat products. Meat Conference Proceed, $43,37-52$.

Sharaf A. M., Ebrahium M. E., Ammar M. S., \& Abd el-Ghany, M. (2009). Influence of using moringa meal flour as meat extender on quality characteristics of beef burger patties during frozen storage. World Journal of Dairy \& Food Science, 4, 32-40.

Singh, G. S. R., Negi, S. P., \& Radha, C. (2013). Phenolic composition, antioxidant and antimicrobial activities of free and bound phenolic extracts of Moringa oleifera seed flour. Journal of Functional Foods, 5, 188-1891.

Tarladgis, B. G., Watts, B. M., Younathan, M. T., \& Dugan, L. Jr. (1960). A distillation method for the quantitative determination of malonaldehyde in rancid foods. Journal of the American Oil Chemists' Society, 37(1), 44-48. http://dx.doi.org/10.1007/ BF02630824.

Trindade, M. A., Thomazine, M., Oliveira, J. M., Balieiro, J. C. C., \& Favaro-Trindade, C. S. (2010). Estabilidade oxidativa, microbiológica e sensorial de mortadela contendo óleo de soja, armazenada a $0{ }^{\circ} \mathrm{C}$ durante 60 dias. Brazilian Journal of Food Technology, 13(03), 165 173. http://dx.doi.org/10.4260/BJFT2010130300022.

Troy, D. J., Desmond, E. M., \& Buckley, D. J. (1999). Eating quality of low-fat beef burgers containing fat-replacing functional blends. Journal of the Science of Food and Agriculture, 79(4), 507-516. http:// dx.doi.org/10.1002/(SICI)1097-0010(19990315)79:4<507::AIDJSFA209>3.0.CO;2-6.

Viuda-Martos, M., Ruiz-Navajas, Y., Fernández-López, J., \& Pérez-Álvarez, J. A. (2010). Effect of added citrus fibre and spice essential oils on quality characteristics and shelf-life of mortadella. Meat Science, 85(3), 568-576. http://dx.doi.org/10.1016/j.meatsci.2010.03.007. PMid:20416839.

Yang, H. S., Choi, S. G., Jeon, J. T., Park, G. B., \& Joo, S. T. (2007). Textural and sensory properties of low-fat pork sausages with added hydrated oatmeal and tofu as texture-modifying agents. Meat Science, 75(2), 283-289. http://dx.doi.org/10.1016/j.meatsci.2006.07.013. PMid:22063660. 